\title{
An Unique Context of Separation of Religion and State in Japan
}

Thomas Makoto Naruse

Department of Law, Kokushikan University

Follow this and additional works at: https://gensoken.toyo.ac.jp/japanese-society-and-culture

Part of the Constitutional Law Commons, and the Religion Law Commons

\section{Recommended Citation}

Naruse, Thomas Makoto (2021) "An Unique Context of Separation of Religion and State in Japan," Japanese Society and Culture: Vol. 3 , Article 10.

DOI: 10.52882/2434-1738-0310

Available at: https://gensoken.toyo.ac.jp/japanese-society-and-culture/vol3/iss1/10

This Article is brought to you for free and open access by Institute of Social Sciences. It has been accepted for inclusion in Japanese Society and Culture by an authorized editor of Institute of Social Sciences. 


\title{
An Unique Context of Separation of Religion and State in Japan
}

\author{
Thomas Makoto Naruse ${ }^{*}$
}

\begin{abstract}
Article 20 of the Constitution of Japan stipulates the separation of religion and state. As in many countries, the primary purpose of the separation of religion and state is to guarantee religious freedom. However, in Japan, the separation of religion and state has the aim of preventing the revival of State Shinto or militarism. From this point of view, Article 20 of the Constitution of Japan can be understood as a kind of "pacifist clause." This article points out the "pacifist" aspect of the separation of religion and state in Japan, based mainly on the drafting process of the current constitution, and plaintiffs' allegations in the suits relating to separation of religion and state.
\end{abstract}

Keywords: Constitution of Japan, Article 20 of the Constitution of Japan, Religious Freedom, Separation of Religion and State, "Pacifist" Aspect of the Separation of Religion and State

\section{Introduction}

Although the principle of separation of religion and state has been adopted in many countries, the principle has a different character in each country. As Professor Sasagawa points out, the separation of religion and state was established in order to overcome historical issues in each country, and should be interpreted on that basis 1 .

Article 20 of the Constitution of Japan stipulates the separation of religion and state ${ }^{2}$. That being the case, what kind of context exists in Japan's separation of religion and state? As in many countries, the primary purpose is to guarantee religious freedom. However, in Japan, it has the aim of preventing the revival of State Shinto or militarism. This can be understood as a kind of "pacifist clause." This aspect of the separation of religion and state is seen in the drafting process of the current constitution, and in arguments in court cases. In particular, the plaintiffs' allegations in lawsuits relating to the separation of religion and state are often based on a "pacifist" understanding of separation clauses.

This article introduces the "pacifist" aspect of the separation of religion and state in Japan. However the Court decisions do not always sympathize with such an understanding, many of the cases relating to separation of religion and state in Japan have pacifism as their main purpose. This article will introduce these two aspects, based mainly on the drafting process of the current constitution, and plaintiffs'

\footnotetext{
※ Lecturer, Kokushikan University, Department of Law

1 Sasagawa Norikatsu, Kenpo to Shukyo-Genriteki na Shomondai ni Tsuite [Constitutional Law and Religionstudies on fundamental problems], 52 Koho Kenkyu 1, 25 (Yuhikaku 1990).

2 Nihonkoku Kenpo [Constitution] [Kenpo] art. 20 (Japan): Freedom of religion is guaranteed to all. No religious organization shall receive any privileges from the State, nor exercise any political authority. (2) No person shall be compelled to take part in any religious act, celebration, rite or practice. (3) The State and its organs shall refrain from religious education or any other religious activity. English translation is referred to: National Diet Library, Birth of the Constitution of Japan: The Constitution of Japan Chapter III. Rights and Duties (visited Sept. 28, 2020)

< https://www.ndl.go.jp/constitution/e/etc/c01.html>.
} 
allegations in the suits relating to separation of religion and state.

2. Separation of Religion and State before the Enactment of the Current Constitution ${ }^{3}$

(1) Separation of religion and state under the Meiji Constitution

Various human rights were guaranteed in the Meiji Constitution as well as current Constitution, but most of them were guaranteed within the "limits of the law." However, Article 28 of the Meiji Constitution states, "Japanese subjects shall, within limits not prejudicial to peace and order, and not antagonistic to their duties as subjects, enjoy freedom of religious belief.4" While many other human rights clauses stipulated "within the limits of the law," this article stipulates "within limits not prejudicial to peace and order, and not antagonistic to their duties as subjects." Given this difference in the grounds for restrictions, it was understood that restrictions on religious freedom by administrative order (rather than by statute) were allowed 5 .

Under the Meiji Constitution, Shrine Shinto was placed in the position of the de facto state religion 6 . As the famous phrase "Shinto is not a religion" indicates, the shrine was treated not as religion but rather as a system of morality and of the duty of subjects. Under the Meiji Constitution, religions other than Shrine Shinto were recognized only to the extent that they were considered to be compatible with the state religion (Shrine Shinto), and sometimes suppression of other religions took place ${ }^{7}$. Shrine Shinto as a state religion also functioned as a spiritual pillar in the execution of war, and people were forced to worship at the shrines ${ }^{8}$. It has also been pointed out that one harmful effect of the connection between Shinto and the state was that State Shinto functioned as a device for execution of war, in addition to the violation of religious freedom.

(2) Separation of religion and state in early postwar policies

As an example from the early post-war period, references to religion are found in the Potsdam Declaration. The Potsdam Declaration demanded the elimination of militarism and thorough democratization, and in its tenth section, stated that "Freedom of speech, of religion, and of thought, as well as respect for the fundamental human rights shall be established ${ }^{9}$." A different document, the "Summary of United States Initial Post-Defeat Policy relating to Japan (Informal and without Commitment by the Department of State)," mentions the guarantee of religious freedom, and also stated that "At the same time it should be made plain to the Japanese that ultra-nationalistic and militaristic organizations and movements will not be permitted to hide behind the cloak of religion ${ }^{10}$.” From this, it can be seen that state religion was understood to be related to militarism and ultra-nationalism.

\footnotetext{
3 My previous article deals with the topic of this part, so there are some overlaps in the contents. See also, Naruse Thomas Makoto, Daijosai and the Separation of Religion and State, 2 Japanese Society and Culture 31, at 34-35 (2020). 4 Dai Nihon Teikoku Kenpo [Constitution] [Meiji Kenpo] art. 28 (Japan). English translation is referred to: National Diet Library, Birth of the Constitution of Japan: The Constitution of the Empire of Japan Chapter II. Rights and Duties of Subjects (visited Sept. 28, 2020) < https://www.ndl.go.jp/constitution/e/etc/c02.html>.

5 Ashibe Nobuyoshi, Kenpo 159 (Takahashi Kazuyuki ed., Iwanami Shoten 7th ed. 2019).

6 Id.

7 Ashibe, supra note 5, at 159.

8 As a view which emphasizes this aspect, see generally, Takahashi Tetsuya, Yasukuni Mondai (Chikuma Shobo 2005).

9 National Diet Library (Japan), Potsdam Declaration (visited Sept. 24, 2020)

$<$ https://www.ndl.go.jp/constitution/e/etc/c06.html>.

10 National Diet Library (Japan), United States Initial Post-Defeat Policy Relating to Japan (visited Sept. 28, 2020) $<$ https://www.ndl.go.jp/constitution/shiryo/01/022/022_001r.html>.
} 
The so-called "Civil Liberties Directive" and "Shinto Directive" are important for the purpose of this article. The official title of the former directive is "Removal of Restrictions on Political, Civil and Religious Freedom (Memorandum of Understanding)," issued by “GHQ,” on October 4, 194511. In this document, it was stated that there was a need to "Abrogate and immediately suspend the operation of all provisions of all laws, decrees, orders, ordinances and regulations which: (1) Establish or maintain restrictions on freedom of thought, of religion, of assembly and of speech ${ }^{12}$." As can be seen, the purpose of the directive was to guarantee the freedom of religion. The directive directly focused on guaranteeing human rights.

On the other hand, the so-called "Shinto Directive13," is more focused on the separation of religion and state. The beginning of the directive stated that its purpose was to (1) "free the Japanese people from direct or indirect compulsion to believe or profess to believe in a religion or cult officially designated by the state 14 ," (2) " lift from the Japanese people the burden of compulsory financial support of an ideology which has contributed to their war guilt, defeat, suffering, privation, and present deplorable condition ${ }^{15}$," (3) prevent “ a recurrence of the perversion of Shinto theory and beliefs into militaristic and ultra-nationalistic propaganda designed to delude the Japanese people and lead them into wars of aggression16," (4) assist "the Japanese people in a rededication of their national life to building a new Japan based upon ideals of perpetual peace and democracy ${ }^{17}$," and so on. The directive stated that the state and Shinto should be separated from the viewpoint of preventing militarism. In this way, the Shinto Directive focused on the separation of religion and state from the perspective of prevention of militarism and ultra-nationalism, rather than directly guaranteeing freedom of religion. These purposes are paraphrased as "pacifism" in a broad sense.

(3) Separation of religion and state in the drafting process of the current constitution

The Japanese government was also aware of the problem with the shrine system. In response to the Potsdam Declaration, the Cabinet Legislation Bureau identified problems with the system ${ }^{18}$. Possible solutions, such as dispelling the religious nature of the shrine, moving authority for shrine administration to the Imperial Household Ministry and designating it as a religion of the imperial house without any special status, or granting specific status to the extent that this does not violate religious freedom as in the Italian constitution, were mentioned ${ }^{19}$.

In the process of enacting the so-called Matsumoto draft, the separation of religion and state was mentioned. In the process of the Matsumoto Committee was identifying the problems, in connection

\footnotetext{
11 National Diet Library (Japan): Modern Japan in archives, Memorandum for: Imperial Japanese Government. Through: Central Liaison Office, Tokyo. Subject: Removal of Restrictions on Political, Civil, and Religious Liberties (visited Sept. 27, 2020) <https://www.ndl .go.jp/modern/img_1/M003/M003-0011.html>.

$12 I d$.

13 Official title is "Abolition of Governmental Sponsorship, Support, Perpetuation, Control, and Dissemination of Shinto.” The text in English is provided: Abolition of Governmental Sponsorship, Support, Perpetuation, Control and Dissemination of State Shinto (Kokka Shinto, Jinja Shinto) (visited Sept. 24, 2020)

$<\mathrm{http}: / /$ dl.ndl.go.jp/info:ndljp/pid/9885515>.

14 Id.

$15 I d$.

$16 I d$.

17 Id.

18 Sato Tatsuo, Nihonkou Kenpo Seiritsushi dai 1 kan [1 History of drafting process of Japanese Constitution] 166 (Yuhikaku 1962).

19 Id. at $166-67$.
} 
with Article 28 of the Meiji Constitution, it was mentioned that "as there is an argument today that advocates placing the shrine in the same category as other religions and separating it from the state, it will be impossible to add a new clause on shrines to the Constitution ${ }^{20}$." Subsequent committees pointed out that it should be clearly stated that the shrine must be treated as a normal religion ${ }^{21}$. It should be noted that the problem of shrines was conceived as an important issue in relation to Article 3 of the Meiji Constitution, which stipulates that the emperor was sacred and inviolable ${ }^{22}$. In the multiple proposals presented after that, the view was expressed that it should be stated clearly that the shrine would not be treated differently from other religions ${ }^{23}$. In later discussions, there was a view that a special status of the shrines should be denied, but there was also a view that it was not desirable to stipulate such a provision in the form of confirming the GHQ directive ${ }^{24}$. There was also the view that the privileged status would be lost by stipulating that a particular religion should not be treated in a discriminatory manner 25 .

What is noteworthy here is the reference to Allied policies. Tatsuo Sato, who played a major role in the process of drafting the current constitution, points out that under the Meiji Constitution, so-called State Shinto received special treatment from the state, was used for the promotion of ultra-nationalism and militarism, and played a major role in Japanese politics ${ }^{26}$. He also points out that freedom of religion was emphasized in the Civil Liberties Directive, while separation of State Shinto from the state, and disconnection of Shinto from ultra-nationalism and militarism were emphasized in the Shinto Directive27. It is also pointed out that GHQ linked State Shinto and the emperor system ${ }^{28}$. It is noteworthy that those involved in the drafting process distinguished the purposes of both directives and understood the separation of religion and state in relation to militarism and ultra-nationalism.

Subsequently, in the draft of January $4^{\text {th }}$, the clause stipulated that "the special privileges that every shrine has ever had shall be abolished.29" The statement that "there is no national religion 30 " was also put forward as an "alternative plan." This proposal was later reported by the newspaper Mainichi Shimbun and caught the eye of $\mathrm{GHQ}^{31}$. However, in the subsequent discussions, it was decided not to mention the shrines and state religions in the constitution, so those words are not found in the subsequent drafts 32 .

Finally, the Matsumoto draft did not include separation of religion and state. However, attention was paid to the problems of the shrine system in the drafting process, and the abolition of the state religion was about to be included until a certain stage. In a cabinet meeting, Minister Matsumoto stated that the religious clause was drafted as a "gesture," mainly due to external considerations, namely American policy toward the shrine system ${ }^{33}$. This indicates that he was aware of American policy, and that such policies had some impact on the drafting process.

20 Id. at 292.

21 Id. at 317.

22 Id. at 217.

23 Id. at 323.

24 Id. at 367.

$25 \mathrm{Id}$.

26 Id. at 378.

27 Id.

28 Id. at 388 n. 4.

29 Sato Tatsuo, Nihonkou Kenpo Seiritsushi dai 2 kan [2 History of drafting process of Japanese Constitution] 490 (Yuhikaku 1964).

30 Id.

31 Id. at 487 n.2.

32 Id. at 507.

33 Id. at 636. 
In the so-called GHQ draft, the separation of religion and state was drafted by the "Civil Rights Committee ${ }^{34}$." of the GHQ In discussions at a meeting of the Steering Committee and the Civil Rights Committee over the first draft, Lieutenant Colonel Roust said, "This Article was designed to prevent the abuse of spiritual authority to political ends 35 " "Japan has been a priest-ridden country for generations and political tyranny has been reinforced by the threat of spiritual punishment ${ }^{36}$ " "It must be made clear to the Japanese that no political authority is attached to any ecclesiastical organization. 37 ,

Article 19 of the GHQ draft is quite similar to article 20 of the current Constitution. The draft of the Japanese Government (the March 2 draft), which was prepared in response to the GHQ draft, made many changes to the human rights provisions ${ }^{38}$. However, the clause relating to the freedom of religion and the separation of religion and state were almost the same as the GHQ draft, and were not a problem in the subsequent article-by-article deliberations ${ }^{39}$. After that, no major changes were made.

The draft made by Japanese government was submitted to the 90th Imperial Diet. In response to a question regarding the reason for mentioning the denial of state religion (in the House of Peers Committee on September 18), Minister of Education Tanaka said that this was a major political principle of modern civilized nations ${ }^{40}$. In addition, he stated that he felt there was a need for this provision based on Japan's experience, and that the shrine system had been the de facto state religion, although there was no formal state religion in the past ${ }^{41}$. It was also mentioned that it could not be denied that the shrine, which had many religious elements, had a particularly close relationship with the state, and also, in the past, the shrine was treated administratively as not being a religion, but following the spirit of the Potsdam Declaration and the directives of the GHQ, state and shrine were separated ${ }^{42}$.

\section{(4) Summary}

As we have seen so far, it is apparent that the aim of the separation of religion and state provisions of the constitution was to dismantle State Shinto in response to introspection regarding the systems that existed under the Meiji Constitution. Professor Urabe points out that the separation of Shinto and state is the main focus of the principle of the separation of religion and state in the current constitution ${ }^{43}$. Professor Yokota also argues for strict application, saying that the separation of state and Shinto is the primary purpose of the separation of religion and state in Japan ${ }^{44}$.

The abolition of State Shinto had two purposes. One was the dismantling of militarism, which is linked to pacifism. This point is strongly reflected in the Shinto Directive. Professor Takayanagi points out that the purpose of the separation of religion and state is to dispel ideological rule by State

34 Takayanagi Kenzo et al. eds., Nihonkoku Kenpo Seitei no Katei-Rengou-koku Sou-Shireibu Gawa no Kiroku ni Yoru I Genbun to Honyaku [The Making of the Constitution of Japan Vol. I Documents] 111 (Yuhikaku 1972).

$35 I d$. at 201

36 Id.

37 Id.

38 For the detail, Sato Tatsuo, Nihonkou Kenpo Seiritsushi dai 3 kan [3 History of drafting process of Japanese Constitution] 77-80 (Sato Isao ed., Yuhikaku 1994).

39 Id. at 120.

40 himizu Shin, Chikujo Nihonkoku Kenpo Shingiroku dai 2 kan, 427 [2 Clause by Clause Record of Deliberations on Japanese Constitution in Imperial Diet] 422 (Yuhikaku 1962).

41 Id.

42 Id. at 427.

43 Urabe Noriho, Kenpogaku Kyoshitu 136-37 (Nihon Hyoronsha 2nd ed. 2006).

44 Yokota Koichi, Nihon ni Okeru Sikyo Bunri Gensoku no Igi, 58-9 Horitsu Jiho. 24, 27 (1986). 
Shinto ${ }^{45}$. In addition, as the relationship with the emperor is mentioned in relation to the issue of Shinto, Professor Sasaki considers militarism and the emperor system by divine right to have been united, and that democratization and the protection of freedom of speech, thought, religion, etc. were promoted as a means to dismantle militarism ${ }^{46}$. In addition, Professor Kobayashi stated that freedom of religion and separation of religion and state were enacted in line with the Shinto Directives and Civil Liberties Directive, and pointed out that, in line with that historical background, the Japanese Constitution stipulated pacifism, incorporating the references to separation of religion and state in article 20, pacifism in article 9 , and the right to live in peace in the preamble, as a unified whole 47 .

At the same time, since freedom of religion was not guaranteed under State Shinto, the dismantling of State Shinto also had the purpose of ensuring freedom of religion ${ }^{48}$. The two purposes of dismantling State Shinto overlap, but they cannot be summarized as just the single purpose of ensuring freedom of religion.

However, there are also views that deny the connection between the Shinto Directive and the separation of religion and state ${ }^{49}$. Professor Ohara, citing Woodard's words, states that the division of GHQ which was involved in the drafting of the Shinto Directive was prohibited from giving information and comments on the drafting of the Constitution, and also notes the differences in the words used 50 , all of which casts doubt on the view that the idea of the Shinto Directive flowed directly into the Constitution 51 .

Even if the GHQ drafters did not directly incorporate the Shinto Directive into the draft, the Shinto Directive was issued before GHQ was involved in the drafting of the Constitution, and due to its importance, it is natural to assume that the basic principles and ideas of the directive would have been shared within GHQ at least to some extent. Also, it was pointed out during the drafting process of the GHQ that "the purpose was to prevent the abuse of spiritual authority for political purposes 52 ." Also, the abolition of State Shinto and the prevention of militarism were linked, including in the early post-war policies. The Matsumoto Committee and the parliament referred to the Shinto Directive, and were aware of it. Professor Annen also states that it seems exaggerating to establish a separation of religion and state to prevent the recurrence of Shinto as a state religion, given that it was a vulnerable entity that was finally established by the protection of the state ${ }^{53}$. Even so, what is important is not whether it was actually exaggerating or not. What is important is what GHQ and other actors thought, and as mentioned above, the connection between State Shinto and militarism is suggested in various aspects. It seems reasonable to think that there were two purposes.

45 Tsu Jichinsai Iken Sosho wo Mamoru Kai ed., Tsu Jichinsai Iken Sosho 185 (Shinkyo Shuppansha 1972).

46 Tsujimura Miyoko \& Yamamoto Hajime, Gaisetsu Kenpo Kommentar 122 (Shinzansha 2018).

47 Kobayashi Takeshi, Naikaku Souri Daijin Yasukuni Jinja Sanpai Sosho ni Okeru Heiwateki Seizonken no Shucho, 203 Aichi Daigaku Hogakubu Hokei Ronshu 229, 232 (2015).

48 As a similar view, Kitahara Hitoshi, Senryo to Shukyo-Hikaku no Naka no Seikyo Bunri Gensoku I, 26-2 Surugadai Hogaku 103, 112 (2013).

49 Not dealt with directly in this paper, but as a work which examined in detail in recent years, see generally, id.

50 In the Shinto Directive "separation of religion and state" was used, but in drafting process of the constitution,

"separation of church and state" was used, and professor Ohhara finds difference in those meanings. Ohhara Yasuo, Shinto Shirei no Kenkyu 339 (Hara Shobo 1993).

51 Id. at 338-39.

52 Takayanagi, supra note 35.

53 Annen Junji, Shinkyo no Jiyu, in Koza Kenpogaku Dai 3 Kan Kenri no Hosho, 210-11 (Higuchi Yoichi ed., Nihon Hyoronsha 1994). 
In this way, the background to the separation of religion and state in the Constitution of Japan was not only freedom of religion, but also the dismantling of State Shinto for the prevention of militarism and ultra-nationalism, which was conceived of as a "pacifist clause." Today, the lawsuits on separation of religion and state often take on the significance of antimilitarism or pacifist proceedings. In the following section, I would like to examine this point by looking at plaintiffs' allegations in some court cases.

\section{Lawsuits on Separation of Religion and State as "Pacifist Lawsuits"}

(1) Lawsuits against Prime Minister Abe's visitation to the Yasukuni Shrine

Lawsuits concerning the Yasukuni Shrine have a particularly strong pacifist nuance compared to other lawsuits on the separation of religion and state in Japan. "Divinities enshrined at Yasukuni Shrine all sacrificed their lives in the course of fulfilling their public duty to protect their homeland," and the number of the enshrined is said to be more than 2,466,00054. Most of them are military personnel, but a wide range of people is enshrined, including military nurses, students who died during mobilization for war work, and those who were executed as war criminals 55 . The Yasukuni Shrine is positioned as a religious organization that memorializes and honors the war dead, but during World War II it was managed by the state, and the emperor worshipped there as a national memorial and honoring facility.

The problem here is the recognition of the role that Yasukuni Shrine played under the previous constitution, especially during the war. Professor Takahashi states that the purpose of the government in privileging Yasukuni Shrine as the "shrine of the emperor," and in holding rituals to honor the war dead as heroic spirits was to (1) soothe the dissatisfaction of the bereaved family and prevent their criticism toward the state, and (2) enable the mobilization of soldiers by giving the highest honor to the soldiers who died in the war ${ }^{56}$. Professor Takahashi claims that it played the function of the "alchemy of emotions," converting the sadness of the bereaved family into honor and pleasure through national rituals ${ }^{57}$. In this way, Yasukuni Shrine is recognized as having played a significant role in supporting the war in the spiritual aspect. In a similar view, Professor Kobayashi points out that State Shinto and unity of religion and state under the Meiji Constitution "became the spiritual pillars of ultra-nationalism and militarism, and especially Yasukuni Shrine in particular functioned as a religious and ideological apparatus that was indispensable for conducting aggressive war and colonization. It functioned as an indispensable religious and ideological device for carrying out colonial rule 58 ."

At the same time, Yasukuni Shrine enshrines the war dead; it was maintained by the government under the Meiji Constitution, and military personnel were promised that they would be enshrined at Yasukuni Shrine after their death in the line of duty. In other words, it was a national memorial and honoring facility. The phrase "meet in Yasukuni" was widely used, and soldiers went to war and died under such circumstances, so there have been many voices requesting that prime ministers should visits Yasukuni Shrine. In other words, the prime minister's visitation is understood as "commemorating the war dead and consoling the bereaved families ${ }^{59}$.” In this way, there is a strong view that Yasukuni Shrine

\footnotetext{
54 Yasukuni Jinja, History (visited Sept.) 25, 2020) < https://www.yasukuni.or.jp/english/about/history.html >. 55 Id.

56 Takahashi, supra note 7 , at 46.

57 Id. at 43-44.

58 Kobayashi, supra note 47, at 232.

59 Momochi Akira, Yasukuni to Kenpo 144 (Seibundo 2003).
} 
is a memorial facility for the war dead, and in the past there have been movements such as submitting a bill to the Diet that proposed the nationalization of the Yasukuni Shrine.

In this way, the Yasukuni Shrine is, on the one hand, a "spiritual military device" and "a symbol of State Shinto," while on the other hand, it is a central facility for commemoration for the war dead. Due to this Janus-faced nature, every time the prime minister visits the Yasukuni Shrine, a huge debate arises and many lawsuits are filed. However, in those cases, in order to overcome the requirement of standing, plaintiffs face the challenge of proving what kind of rights were violated 60 . Therefore, violations of various rights are alleged in the lawsuits. In addition, the alleged violations have become more diverse in the course of the proceedings 61 .

The character of the proceedings as a "pacifist law suits" is particularly remarkable in the suits against Prime Minister Abe's visitation to Yasukuni. The cases were filed in Osaka and Tokyo, but the complaint of the Tokyo suit first stated that in addition to religious freedom, democracy would be destroyed by the violation of separation of religion and state ${ }^{62}$. Also, a characteristic of the suits against Prime minister Abe's visitation is that more focus is placed on the allegation of violation of the "right to live in peace" In the complaint of the Tokyo suit, the Yasukuni Shrine was described as "a facility that honors those who died in the aggression war, and by extension, it is a facility that praises the aggression war itself. The significance of the Yasukuni Shrine is as a facility to praise death in a war for the country by honoring the heroic spirits of war dead. Therefore, it is clear that it has inherited the spiritual foundation of Japan during the military era ${ }^{63}$," then states that it is clear that the Prime Minister's visit is "beautifying and praising the war by replacing the logic as if the death in the war itself was something precious ${ }^{64}$," and concludes "defendant Abe's visit was made to realize his creed or political policy, and with no other purpose than to prepare a wider range of Japanese people spiritually for accepting war65." Furthermore, "it should be said that the visit to the Yasukuni Shrine and the acceptance of the visit by the Yasukuni shrine have the nature of preparing for war66." Even before the suits against Prime Minister Abe's visit to Yasukuni Shrine, several lawsuits were filed against former Prime Minister Koizumi's visitation to the Yasukuni Shrine, and among those suits, the "right to live in peace" was alleged in suits filed in Fukuoka, Naha, and Chiba. The allegations regarding the "right to live in peace" had been seen previously but have become more emphasized in the current cases ${ }^{67}$.

The case was dismissed by the Tokyo High Court due to lack of standing68. Plaintiffs said in a statement in protest against the district court decision that Prime Minister Abe's visit was "an act of instilling the Yasukuni's idea that it is honorable to die for the country into people and establishing a spiritual foundation to proceed toward war69."

60 Naruse Thomas Makoto, Abe Shusho Yasukuni Sanpai Sosho ni Tsuite IOn a Case against Visitation to the Yasukuni Shrine Done by Prime Minister Abe], 35 Shukyoho 1 (2016).

61 See generally, id.

62 Abe Yasukuni Sanpai Iken Sosho no Kai Tokyo, Sojo (visited Sept. 27, 2020)

$<\mathrm{http}: / /$ seikyobunri.ten-no.net/sojyo.html>

63 Id.

64 Id.

65 Id.

66 Id.

67 Naruse, supra note 60, at 12-15.

68 Supreme Court of Japan (visited Sept. 26, 2020) <https://www.courts.go.jp/app/files/ hanrei_jp / 236/088236_ hanrei.pdf> (High Ct., Oct. 25, 2018).

69 Abe Yasukuni Sanpai Iken Sosho no Kai Tokyo, Sojo (visited Sept. 25, 2020)

$<$ http: //seikyobunri.ten-no.net/news.html . 
(2) Other lawsuits on separation of religion and state

In addition to the lawsuits relating to visitations to the Yasukuni Shrine, there have been other cases that are related to Yasukuni in different ways ${ }^{70}$. For example, in the lawsuits relating to the monument for the war dead in Mino City, Buddhist and Shinto ceremonies were held alternately in front of the monument for the war dead ${ }^{71}$. As the monument for the war dead was removed due to the expansion of an elementary school, the city purchased an alternative site and relocated the monument at public expense, and then lent the land to the local war-bereaved families association (izokukai), which maintained the monument ${ }^{72}$. In addition, the head of the board of education and other public figures attended the commemoration ${ }^{73}$. In this case, a lawsuit was filed against them for violating the separation of religion and state ${ }^{74}$. The plaintiffs pointed out that the "circle of heroic spirits of war dead," which is an essential element of the execution of the war, consists of education, recruitment, combat/death, commemoration, and education. 75 They aimed to cut off the "commemoration" which is an element of this cycle, in order to prevent war from occurring again in the future ${ }^{76}$. Although this case did not deal with the Yasukuni Shrine directly, a relationship with Yasukuni was claimed throughout 77 .

In the Tsu Jichinsai (Shinto groundbreaking ceremony) case, which is a landmark case of the separation of religion and state in Japan, plaintiffs pointed out that the purpose of the provisions of separation of religion and state is to dispel the ideological control by State Shinto ${ }^{78}$. In the oral argument, it was mentioned that State Shinto was the conceptual basis of militarism/totalitarianism, and that this fact underlies the separation of religion and state in the Japanese Constitution ${ }^{79}$. During the proceedings of the case, a group was formed to support the plaintiff's pursuit of the lawsuit, and its establishment prospectus stated that "State Shinto, which was once a spiritual pillar of militarism, will be revived by the nationalization of the Yasukuni Shrine 80 ." It has been pointed out that if the groundbreaking ceremony had been officially approved due to defeat in this case, the impact would have been great ${ }^{81}$. One of the plaintiffs' defense counsel later stated that the suit was a fight against the movement toward returning to the pre-war society ${ }^{82}$. The characteristics of the suit have also been discussed in connection with the issue of nationalization of the Yasukuni Shrine, and this view is also one that links the separation of religion and state, State Shinto, and Yasukuni 83.

In another case, the Sunagawa lawsuit, the Court decided that the free lending to a shrine of cityowned land was a violation of the separation of religion and state. In that case, plaintiffs argued that the

70 Although not directly dealt with in this paper, the Ehime Tamagushiryo case is also mentioned as an example. 51-4 Minshu 1673 (Sup. Ct., Apr. 2, 1997.)

71 47-3 Minshu 1687 (Sup. Ct., Feb. 16, 1993). In this article, cited from following website; Supreme Court of Japan (visited Sept. 26, 2020) <https: / /www.courts.go.jp/app/files/hanrei_jp/361/056361_hanrei.pdf> at 2.

72 Id. at $2-3$.

73 Id. at $11-12$.

74 Kumano Katsuyuki \& Minoh Chukon-hi Iken Sosho Genkokudan, 298 Nin ha Naze Shindaka-Minoh-shi Izokukai Hojokin Iken Sosho Arai Ken Shogen-shu 7 (Epic 2009).

75 Id.

76 Id.

77 See generally, id.

78 Tsu Jichinsai Iken Sosho wo Mamoru Kai, supra note 45, at 19.

79 Imamura Tsuguo, Hi-joukokunin gawa Benron Youshi, in Saikosai to Kamigami-Zoku Tsu Jichinsai Iken Sosho no Kiroku 143, 166 (Tsu Jichinsai Iken Sosho wo Mamoru Kai ed. Shinkyo Shuppansha 1980).

80 Tsu Jichinsai Iken Sosho wo Mamoru Kai, supra note 45, at 428.

81 Id.

82 Koike Kenji, Jichinsai Jiken de Arasowareta noha Nanika-Jiken no Keika to Soten, in Saikosai to Kamigami-Zoku Tsu Jichinsai Iken Sosho no Kiroku 3, 14 (Tsu Jichinsai Iken Sosho wo Mamoru Kai ed. Shinkyo Shuppansha 1980). 83 Id. at $7-8$ 
purpose of the separation of religion and state is to prevent the connection of state and shrine, in order not to restore State Shinto ${ }^{84}$. In the oral argument, the plaintiffs also argued that the connection between the state and Shinto caused the war ${ }^{85}$.

However, the judgements of the Court have generally seen the fundamental purpose of separation of religion and state as being that of guaranteeing religious freedom, and academics have also focused on the aspect of religious freedom as the purpose of separation of religion and state. In the Tsu Jichinsai case, the Court mentioned the history of oppression of religious freedom under the connection between the state and State Shinto, and also mentioned the Shinto Directive, but stated that the Japanese Constitution defines separation of religion and state in the following terms: "in light of the deleterious effects of the close ties that had existed between the State and Shinto since the Meiji Restoration, the Constitution of Japan ... guaranteed unconditional freedom of belief and further strengthened that guarantee by establishing the Provisions on Religion-State Separation ${ }^{86 . " ~ I n ~ a d d i t i o n, ~ t h e r e ~ w a s ~ a ~}$ reference to "the fundamental purpose of the system is to ensure the freedom of religion ${ }^{87}$." The Court also referred to Article 20 (3) of the Constitution as the "stipulation that guarantees the separation of religion and state as a system by, directly, setting the range of actions that the nation and its agencies cannot perform, and thereby attempts to guarantee the freedom of religion ${ }^{88}$." As seen above, the focus is placed on the freedom of religion in this case. This view is also found in later cases ${ }^{89}$, and a gap exists in relation to the plaintiff's understanding in many cases.

\section{Conclusion}

As we have seen, there were two contexts in Japan's principle of separation of religion and state, which were: guaranteeing religious freedom, and preventing the revival of State Shinto. Especially in relation to the latter, it can be said to be a pacifist provision. Regarding this point, in addition to Professor Kobayashi's argument mentioned above, there is a view that the separation of religion and state is understood as a right which includes the "right to live in peace ${ }^{90 "}$. Professor Sasaki, based on the understanding that the purpose of the Shinto directive was to dismantle State Shinto, states that it is not enough to consider the separation of religion and state only in the context of guaranteeing the freedom of religion; rather, it should be seen in connection with pacifism, as in chapter 2 of the Constitution, and also with the emperor system, as in chapter 1 of the Constitution ${ }^{91}$. These two aspects already appeared before the enactment of the current Constitution. Although the judgements of the Court have focused on the aspect of religious freedom, the other aspect is still alive and often becomes the motive for lawsuits

\footnotetext{
84 Sunagawa Seikyo Bunri Sosho Kiroku Hensan Iinkai, Shiyuchi ni Jinja ha Iken!-Sunagawa Seikyo Bunri Sosho no Kiseki 11 (2013).

85 Id. at $42-43$.

86 31-4 Minshu 533 (Sup. Ct., Jul. 13, 1977). In this article, cited from following website; Supreme Court of Japan (visited Sept. 26, 2020) <https://www.courts. go.jp/app/files/hanrei_jp/189/054189_hanrei.pdf> at 3-4.

87 Id. at 5.

88 Id. at 6-7.

89 47-3 Minshu 1687 (Sup. Ct., Feb. 16, 1993). In this article, cited from following website; Supreme Court of Japan (visited Sept. 26, 2020) <https://www.courts.go.jp/app/files/hanrei_jp/361/056361_hanrei.pdf> at 9. 64-1 Minshu 1 (Sup. Ct., Jan. 20, 2007). In this article, cited from following website; Supreme Court of Japan (visited Sept. 26, 2020) <https://www.courts.go.jp/app/files/hanrei_jp/347/038347_hanrei.pdf at 10.

90 Miyamoto Eizo, Seikyo Bunri to Heiwa-teki Seizonken ni Tsuiteno Ichikosatsu-Jinken to Shiteno Seikyo Bunri to Jinken to Shiteno Heiwa, in Heiwa to Kokusai Kyouchou no Kenpogaku 385, 399 (Sugihara Yasuo et al. eds. Keiso Shobo 1990).

91 Tsujimura \& Yamamoto, supra note 46, at 124.
} 
regarding the separation of religion and state.

The Constitution of Japan is a constitution that was created based on introspection in relation to the war and to the way things operated under the previous Constitution. The fundamental principles of the current Constitution are national sovereignty, respect for basic human rights, and pacifism. Since each of the fundamental principles is not isolated but complementary to each other ${ }^{92}$, many articles are connected to pacifism in one way or another. However, the aspect of "pacifism" is particularly pronounced in the separation of religion and state, and it forms the unique context for the separation of religion and state in Japan.

92 Ashibe, supra note 5, at 36-37. 